\title{
The Production-Consumption-Mediation Paradigm
}

\author{
Abstract \\ This article elaborates a production-consumption-mediation paradigm in design history, to \\ examine both the development of design history over the past three decades and the current and \\ future practice of design history, specifically within the UK. While John A. Walker made the case \\ in 1989 for increased design historical attention to be paid to issues of consumption, this article \\ identifies mediation as a third stream in design history, with three prongs: first, the mediation \\ emphasis continues the consumption turn within design history by exploring the role of channels \\ such as television, magazines, corporate literature, advice literature and so on in mediating \\ between producers and consumers and forming consumption practices and ideas about design; \\ second, the mediation emphasis examines the extent to which mediating channels are themselves \\ designed and therefore open to design historical analysis - indeed, these channels have \\ increasingly constituted the design historian's object of study; third, the mediation emphasis \\ investigates the role of designed goods themselves as mediating devices. The identification of the \\ PCM paradigm, and the discussion of the methodological and interdisciplinary issues arising \\ provided here, including the relationship of design history to neighbouring fields, have \\ implications for conceptions of the field of design history, in both content and approach.
}

\section{Keywords}

Historiography - Methodology - Production - Consumption - Mediation - PCM Paradigm 


\section{Introduction: From the Production-Consumption Model to the Production-Consumption- Mediation Paradigm}

It is difficult to summarize lengthy and complicated processes, such as the development of a discipline, within the scope of an article. However, the attempt itself is useful. In so doing, it is necessary to systematize the evolution of design history. An earlier attempt to systematize understanding of the workings of design history occurred exactly twenty years ago when John A. Walker published Design History and the History of Design, a methodological review of the discipline, outlining a range of approaches to design historical work for the benefit of students. While various chapters of Walker's book examine work on detached parts of the lifecycle of designed objects, including ‘Designers and Design Goods: the Proper Objects of Study?' and 'Consumption, Reception, Taste', a central chapter outlines Walker's 'Production-consumption model': 'a general model of the production, distribution and consumption of design... presented diagrammatically' in order that we might 'see at a glance where a particular study belongs and ... identify those topics which currently receive little attention. ${ }^{1}$ [Fig.1] Referring to Marx, Walker noted that while 'for the purposes of exposition and clarity, the two processes of production and consumption are treated separately in a linear, sequential order ... it should be recognized that in practice the two processes are interdependent. ${ }^{2}$ Thus Walker acknowledged the artificiality of his diagrammatic representation of the discipline.

This article ${ }^{3}$ elaborates another necessarily systematized account of the discipline of design history. The Production-Consumption-Mediation paradigm (PCM paradigm) is a new contribution, based upon the findings of a review of more than three decades of the literature of design history. ${ }^{4}$ In recognising that the PCM paradigm is a systematised account, it should be noted that, just as Igor Kopytoff proposes a biography of things, ${ }^{5}$ in which objects are imbued with a variety of meanings at different times according to their age and context, so this article accepts that texts have their own reception histories, which are not always compatible with 
authorial intention. The licence to presume to comment on the work of others in this way is informed by the post-structuralist literary theory of Roland Barthes and the historical methodology of Hayden White. ${ }^{6}$ It is also worth pointing out that the focus of this article is design history, not design. The article does not seek to define design, or the sort of design that should be studied by design historians. Rather, it is concerned exclusively with what design historians have considered that design history should be. Finally, it may be necessary to make clear that this historiographic article discusses design history which sought to promulgate a canon of design and design history which sought to dismantle that canon, does not in itself amount to another canon, of design historical texts. Contributions to design history are discussed here without judgments being made about their quality, and omission is not intended to signify inferiority or irrelevance. The selection of texts mentioned here is not intended to be comprehensive and I question whether such an intention is achievable within the confines of an article, or even desirable.

The PCM paradigm is differentiated from Walker's 'Production-Consumption model' in several fundamental ways. Firstly, it includes scholarship during the twenty years since Walker's book appeared. While Walker made the case for increased design historical attention to be paid to issues of consumption, this article identifies mediation as a third stream in design history popularised as a result of developments in the 1990s and subsequently, and argues for its utility as a category in understanding the development of current and future practice in design history. What is foregrounded in the PCM paradigm as 'mediation' is not credited with a titular position in Walker's 'Production-Consumption Model'. ${ }^{7}$ Walker did acknowledge what we can now term 'mediating channels': a quarter of his linear diagram is give over to 'distribution' which includes marketing, advertising, exhibitions and retail; museums and consumer associations appear in 'consumption' and his separate discussion of 'Discourse and Meta-Language' serves as a prediction of the emphasis on mediation. [Fig. 2] It is not, therefore, recognition of the mediating 
channels themselves which is new - Walker acknowledged them twenty years ago - but rather the critical mass which has built up around mediation as a useful focus for understanding design.

The PCM paradigm is further differentiated from Walker's 'Production-Consumption model' through the degree to which each presents design history synchronically or diachronically, that is as a snapshot of one moment or as a developmental history. ${ }^{8}$ Walker recognised successive preoccupations within design history, as shall be discussed later in this article. However, Walker's 'Production-Consumption model' aimed to situate individual studies in relation to one another, within the context of the entire field. No attempt is made to indicate the points in time at which specific studies were undertaken, nor does the model characterise patterns of interest across the development of design history. The temporal element in Walker's largely synchronic model is confined to the lifecycle of the object, and as he admits this is presented in an artificially linear, rather than cyclical, format. This observation is not made as a criticism of Walker's model, but rather to point out its distinction from the paradigm set out in this article.

Just as Walker's 'Production-Consumption Model' is best described as largely, but not entirely, synchronic, so the PCM paradigm is only partially diachronic. Just as Walker artificially represented a cyclical process in linear form, for the sake of clarity and explication, so this article separates out the three overlapping concerns of production, consumption and mediation in an artificial sequence. It is crucial to recognise that no single issue has, or should have, the ability to dominate a discipline to the exclusion of all others, and the PCM paradigm is not intended to imply a linear model of three successive stages in the development of design history. Rather, it identifies three core issues which have achieved prominence at different points in the development of design history and which now co-exist among the varied and interdisciplinary range of approaches available to design historians. 
While Walker used the term 'model' for his systematised representation of the work of design history, here the term 'paradigm' is used. The terms 'production', 'consumption' and 'mediation' are discussed in the main body of this article; here it is worth reflecting on the word 'paradigm'. The word has been variously defined and hotly contested across the sciences, social sciences and humanities, most prominently in the work of Thomas Kuhn and his detractors. ${ }^{9}$ The difficulty of defining the term 'paradigm' has itself become noteworthy among scholars, as Egon Guba points out in the introduction to his edited collection of conference papers, The Paradigm Dialog:

Thomas Kuhn, the person most responsible for bringing that concept into our collective awareness, has himself used the term in no fewer than 21 different ways, if Masterman (1970) can be believed. Some persons view that lack of clear definition as an unfortunate state of affairs. But I believe that [...] having the term not cast in stone is intellectually useful. $^{10}$

'Paradigm' is used here to indicate that the model outlined concerns the way a series of concepts interrelate to produce a framework which informs understanding of the development of design history and future work in the discipline. This article makes no claims to paradigm-shifting; it simply proposes a paradigmatic understanding of design history as focussed upon three emphases, as one interpretation among several.

The article begins by reviewing two core issues which achieved prominence prior to a current concern for mediation within design history and have continued relevance today. It notes in the origins of British design history, in the 1970s, an attempt to assert the discrete disciplinary status of design history through the study of selected designs, designers and manufacturers, informed by the preference for modernist exemplars promoted forty years earlier by Nikolaus Pevsner. Individual designers or companies continued as useful foci for design historical analysis, while a response to critiques of the Pevsnerian influence in design history, and its masculine bias towards particularised versions of professional production, informed an increasing emphasis on issues of consumption during the 1990s. While critics argue that consumption has been insufficiently well defined to form a cogent area of study, consumption remains attractive to design historians 
seeking a more holistic understanding of design than that allowed by an emphasis on professional design and manufacturers. A focus on mediation provides design historians with a third stream which brings together issues of production and consumption, illuminating not only the importance of mediating channels such as magazines and television in forming consumption practices and ideas about design, and the extent to which those channels are themselves designed and therefore open to design historical analysis, but also illuminating the role of designed goods as mediating devices; mediating identity, mediating between individuals, the world is mediated through objects which are designed. The identification of the PCM paradigm, and the discussion of the methodological and interdisciplinary issues arising provided here, including the relationship of design history to neighbouring fields, have implications for conceptions of the field of design history, in both content and approach, present and future. Mediation is best understood as an additional emphasis within design history, which complements object-based analysis and enriches understanding, as well as providing a useful basis for future work in the discipline.

Given the serious efforts currently being made to globalise design history, it should be noted that the PCM paradigm is intended to reflect developments within the UK specifically. Although this article is informed by debates in the US and, less directly, by design historical work from other regions, it does not intend to offer a global picture and if the PCM paradigm is found to be useful in understanding the place of mediation within design history outside of the UK, then that will be a bonus beyond the article's remit.

\section{I - The Production Emphasis and Design Education, Designers and Manufacturers}

The origins of a design historical tendency to privilege production, through studies of designers and manufacturers and designed goods, extend from two related aspects of the genesis of design history in the UK: the discipline's roots in art and design education and the enduring influence of

Nikolaus Pevsner. The former is a familiar story, variously told, so here a summary will suffice. ${ }^{11}$ 
Design history in Britain has an established (albeit diminishing) institutional base in the UK derived from two influential reports to government in 1960 and 1970 which recommended that for art and design subjects to achieve BA Honours degree status, they must carry a contextual, written element. ${ }^{12}$ Early teachers of the subject, such as Gillian Naylor and Penny Sparke, began writing design history texts partly as a way of generating teaching materials for their students. ${ }^{13}$ While early design historical scholarship was aired at panels within the Art Historian's conference, British design history was formalised when some delegates at an Association of Art Historians conference in 1977 set up the Design History Society to 'consolidate design history as a distinct field of study' and a separate UK conference of Design Historians became an annual fixture. ${ }^{14}$ What is variously known as historical / critical / contextual / cultural studies, or some related term or acronym, still forms part of most UK art and design programmes. A connection may be drawn between a design historical tendency to privilege production and the taste among students, as emergent designers, for information about the careers of successful practitioners and companies, from which they hope to find exemplars and learn the secrets of success.

\section{Design History - In Good Shape?}

Design history emerged in Britain in the 1970s, but a much earlier text - Nikolaus Pevsner's Pioneers of Modern Design of 1936 - was especially influential upon the discipline's tendency to celebrate the work of exceptional designers, producers or objects, mostly drawn from the modern movement. ${ }^{15}$ Pevsner's work, and that of his followers, promoted the work of designers partly in order to promote the study of design. Books such as Stephen Bayley's In Good Shape of 1979 and Deyan Sudjic's Cult Objects of 1985 exemplify a popularised form of the Pevsnarian aim of championing excellence - forming, indeed, a canon of good design - and prioritising an aestheticised understanding of design appreciation akin to a now-outmoded art historical approach based on a history of styles and connoisseurship. ${ }^{16}$ 
That In Good Shape occupies a precarious position between the traditions of art history and the novelty of design history is exemplified in its front matter: while Lord Reilly, ex-Director of the Council of Industrial Design, describes the author as 'that rare bird a historian of modern design', Bayley himself acknowledges in the 'Preface' that 'this is a very traditional book' ${ }^{17}$ In Good Shape focuses on the formal qualities of objects which result from decisions made by designers, and manufacturers' constraints. It comprises an essay 'Industrial Design in the Twentieth Century' and sections providing key texts by designers and design commentators, biographies, timeline, bibliography, and, in the form of a list, a series of images of objects.

Cult Objects is composed of eight chapters, half thematic and half dealing with object typologies (clothes, furniture, packaging and transport), all written in a stylised journalistic register. Sudjic defines his subject thus:

Cult Objects [...] all have special qualities over and above what one could be entitled to expect from the simple considerations of performing a function [...] they all share that element of effortless rightness, or belonging, and the ability to communicate which are the essential ingredients of a cult object. ${ }^{18}$

The book is subtitled 'The complete guide to having it all', a reminder that it was written and read within a specific context: during the 1980s, awareness of the capacity of overtly 'designed' goods to express affluence and aspirations intensified and of government support of design as a tool for business, both of which are implied in the labelling of the period as the designer decade.

In Good Shape echoes MoMA curator Philip Johnson's Machine Art of 1934 - published two years before Pevsner's Pioneers - in presenting selected objects in a catalogue of highly formalised black and white photographs. For example, in addition to the iconic 'Self-aligning ball bearing' featured on the cover, Machine Art shows sections of wire rope arranged in a floral motif, and a set of graduated ladles fanned out across the picture space. ${ }^{19}$ [Fig. 3] Machine Art is 
an exhibition catalogue in which a list of lenders, an introductory essay, and a catalogue listing precede numbered images with captions giving object typology, manufacturer, designer and price. Bayley's book uses images in two ways: thumbnails accompany the texts and the section 'Products' offers a 'selection of photographs' arranged chronologically with a short paragraph of evaluation from the author. Cult Objects combines text and image more completely to offer illustrated narrative chapters with mainly large format images and some thumbnails. The distribution of text and image is nearer to Pevsner's Pioneers. Machine Art, In Good Shape, and Cult Objects are each distinguishable in terms of the relationship of the text and the images; however, the images themselves are remarkably similar.

Aside from appearances, each book upholds different ideas about what constitutes 'art' and 'style' in designed goods. While Machine Art presents a pared-down selection of 'Industrial Units', 'Scientific Instruments' and 'Laboratory Glass and Porcelain' alongside 'Household and Office Equipment', 'Kitchenware' and 'House Furnishings and Accessories', Bayley's taste is broader, and not only because he was able to feature goods produced after Machine Art appeared. He notes, for example, of Gio Ponti's coffee machine for La Pavoni (1949) that it 'relies on the idioms of art deco and the American automobile industry'. [Fig. 4] Sudjic is interested in the way in which the group of objects he has selected has been accorded the ability to imbue users or owners with various desirable qualities and status. [Fig. 5] This expressiveness is quite different to the MoMA ideal, as inferred by Terry Smith in his critique 'Pure Modernism, Inc', that 'the artist-designer seeks, in the design process, the anonymity, the invisibility of the technical designer'. ${ }^{20}$ Each approach, however, depends upon an appreciation of the formal qualities of design, derived from museological practices based on connoisseurship and the history of styles in decorative arts. 
In his 1988 book Design History Australia, Tony Fry singled out Bayley’s In Good Shape as exemplifying connoisseurship in design history. ${ }^{21}$ In so doing, Fry rather dismisses connoisseurship which can also be seen as a vast repository of typological knowledge based on first-hand close scrutiny of objects. Fry's categories of design historical approaches include - in addition to connoisseurship - 'canonisation', 'the object in space', 'the common object' 'design as culture', 'design and gender' and 'design as economy', sequenced according to their proximity to Fry's own methodological preferences. Put within the terms of the PCM paradigm, connoisseurship and canonisation fit into the production focus.

The emphasis on greats that followed Nikolaus Pevsner's Pioneers of Modern Design, and emulated a model, being abandoned in art history, of history as a succession of period styles, prompted a number of critiques. Pevsner's own work was the target of criticism, most notably by Reyner Banham, in what American Studies scholar Jeffrey L. Meikle has called Banham's 'devastating revision of Nikolaus Pevsner'. ${ }^{22}$ Such devastation is traced by Nigel Whiteley in terms of the successive stages of a teacher-student relationship. ${ }^{23}$ However, Guy Julier and Viviana Narotsky echoed Tony Fry's text of a decade earlier, in pointing out that Banham's Theory and Design in the First Machine Age, of 1960, 'reworks notions of functionalism, but still discusses the same objects, people and lineage as Pevsner. ${ }^{24}$ More broadly, they criticize 'a continued myth and fetishization of modernism as a dominant paradigm of design history'. ${ }^{25}$ In this, they again recall Fry who complained that:

Design history and the design typeform is therefore fully implicated in the production of the design object as fetish. This is to say that reification, aestheticisation, decontextualisation and recontextualisation are all orchestrated institutionally by design history as either writing, curatorial practice, pedagogy of any combination of these agencies. $^{26}$

Fry preferred a design history which refuses to fetishize the object and recognises that: 'The "design object" is constituted in and has no independent existence outside discourse. This is to say that it is a product of theory rather than simply an object in the world which is directly 
observable. ${ }^{, 27}$ In according such importance to discourse and mediation, Fry anticipated a growing tendency within design history.

\section{A Transatlantic Debate}

As noted above, this article does not presume to examine design history beyond the UK.

However, the nature of the design historical project has been vigorously debated within and without the UK and of course this debate has impacted upon the practice of British design history. ${ }^{28}$ A noteworthy transatlantic debate on the nature of the discipline, its content and its limits, continued for more than a decade from 1984 onwards. Writing in 1984, Clive Dilnot asserted that 'design history, in the sense of a single, organized discipline with defined aims and objects, does not exist'. This absence did not prevent him from characterising design history in general: 'Design history emphasizes individual designers. Explicitly or implicitly, they are the focus of the majority of design history written and taught today.' Dilnot called for increased 'socio-historical understanding' to improve the situation. ${ }^{29}$ Dilnot's twin articles formed an early warning. A later turf war occurred following the publication of Victor Margolin's provocative 1992 critique of design history's subject matter and methodology, and promotion of his conception of design studies as superior. ${ }^{30}$ These early reviews of design history complained about the lack of a clear shared idea of design for design history to explore and sought to delimit and define design and its histories as part of establishing a discipline with scholarly integrity.

Adrian Forty's 'Reply to Victor Margolin' defended the rights of design historians to repeatedly return to the question of defining quality in design and to refuse disciplinary boundaries by insisting that design historians were already producing contextualised and methodologically selfreflexive work.

Some of the most interesting work in design history recently owes its interest to the influence of other disciplines. It is particularly from the field of cultural studies and 
anthropology that design history has benefited, since these are fields that have enabled people to research into consumer behaviour and its relation to the design of goods. ${ }^{31}$

Indeed, Forty's own Objects of Desire: Design and Society since 1750 exemplifies the contextualised approach, if not the methodological self-reflexivity, which Margolin regarded as lacking, even while Margolin and Forty cannot be regarded as agreeing about what the nature of the design historical project. ${ }^{32}$ Forty explored examples of product changes made by manufacturers in anticipation of, or in response, to consumer preferences. While Tony Fry has criticised Forty's book for presenting design as being merely influenced by abstracted historical forces, for failing to examine the notion of desire and for its 'arbitrary and unsystematic' thematic organisation, ${ }^{33}$ it succeeded in demonstrating to a wide readership the importance of situating design within social context. The debate continued: Margolin's and Forty's initial articles were reprinted along with other contributions, in a special issue of Design Issues, which included Jonathan Woodham's defence of design history and Margolin's 'Reply to Adrian Forty'... ${ }^{34}$

While, happily, methodological concerns remain open for debate ${ }^{35}$ design history has the confidence to proceed without definitive definitions of design and design history to which we must all adhere. We should value precisely that work which seeks to extend our understanding of design activity. For example, Mary Guyatt's writing for this journal has ranged from Wedgwood's Slave Medallion to artificial limbs. ${ }^{36}$ Scholarship is a collective dialogic process, operating through difference as well as consensus. Methodological reflections such as those provided by Dilnot, Margolin, Woodham and Forty were not only invaluable to contemporary readers; they are also useful in retrospectively tracing disciplinary concerns.

Excellent and illuminating work which privileges production has been a continuing aspect of design history up to the present. Thoroughly contextualised accounts of named designers or manufacturers (whether modernist or not), have formed an important strand of the British design 
historical project, from early examples such as Penny Sparke's book on Ettore Sottsass and John Heskett's account of Philips, to Tanya Harrod's survey of British craft. ${ }^{37}$ Judy Attfield, Clive Edwards and Christopher Breward - to name but a few design historians who have worked in Britain - have demonstrated that production remains an important emphasis within design history and the designer and manufacturer continue to be useful foci for analysis. ${ }^{38}$

\section{II - The Consumption Emphasis: Design History and Interdisciplinarity}

Early critiques of design history articulated a need to add to the profiles of key designers of the modern movement aspects of design history not told through an emphasis on producers. Following the publication of Forty's 1986 Objects of Desire, which examined the impact of consumers on design and manufacture as part of its attempt to place design within social and economic context, ${ }^{39}$ Walker wrote in 1989:

In the main, design historians have focused upon aspects of production - designers, designing, manufacture - and the analysis of products rather than upon an equally crucial dimension - the role of users and consumers. I am including a brief discussion of consumption, reception and taste to correct this imbalance. ${ }^{40}$

In retrospect, we can see that Walker was correct to herald consumption as an important preoccupation for design history of the 1990s, even though some contributions to consumption studies, such as Forty's Objects of Desire, appeared before 1989 and consumption has remained a core interest within design history since the nineties.

Social and economic historians Matthew Hilton and Martin Daunton attribute the scholarly interest in consumption to 'both the political emphasis placed on consumerism by the Conservative and Republican governments of the 1980s and from the earlier critiques of consumer society offered by scholars such as Guy Debord and Jean Baudrillard. ${ }^{, 41}$ Design history's consumption turn bore the influence of developments in cultural theory. Forty's aforementioned Objects of Desire (1986), Penny Sparke's Introduction to Design and Culture, 
1900 to the Present (1986) and Tony Fry's Design History Australia (1988) each exemplify

theoretical outlooks in the writing of design history. ${ }^{42}$ Hilton defines the core interests of consumption studies as:

the means by which identities are established in a commodified world, whether by the conscious actions of consumers themselves, the deliberate manipulation of their desires by the marketing and sales experts, of by the interaction of people with a range of goods, the function of which is hidden beneath an enormous array of symbolic meanings and imagery. ${ }^{43}$

Far from representing attempts to define a singular design historical methodology, or to replace one focus with another, part of this shift related to recognition of the benefits of interdisciplinary approaches to the understanding of design history. When The Journal of Design History appeared in 1988, just over a decade after the inception of the Design History Society, the opening editorial recognised that the 'design historian is accustomed to the contingency of many disciplines, and the Journal must reflect that. ${ }^{44}$

French literary theory of the Structuralist and Post-Structuralist schools, and particularly the work of Roland Barthes has been especially useful to design historians. The essays selected for Mythologies (translated into English in 1972) and Image-Music-Text, (translated in 1977), popularised the idea, within design history, that the reader/consumer can be as important as the writer/producer in making meaning for cultural artefacts. ${ }^{45}$ Walker uses the literary categories of readerly and writerly registers, meta-discourse, synchronic and diachronic emphases to explain different kinds of design history writing and refers to Barthes’ Mythologies as an exemplar of object analysis. He reviews 'Structuralist and Semiotic approaches to design' in his examination of 'varieties of design history" ${ }^{46}$ By using analytical strategies informed by Saussurian linguistics and anthropological understanding of myth and symbol, design historians were able to reveal a new significance for the consumption of designed objects in cultural and social contexts. Forty, too, discusses the utility of Structuralist theory for understanding designed objects, noting that: 
'Unlike the more or less ephemeral media, design has the capacity to cast myths into an enduring solid and tangible form, so that they seem to be reality itself. ${ }^{47}$ Forty makes clear the ways in which the mythic ability of design can be harnessed for commercial gain.

The approach to consumption within design history has also been inspired by British cultural studies, ${ }^{48}$ centred upon the Birmingham Centre for Contemporary Cultural Studies. Influential texts include Richard Hoggart's readings of the consumption of popular culture and Dick Hebdige's Marxian work on incorporation and the role of consumers in generating meanings and practices around objects. ${ }^{49}$ While designers and manufacturers may intend one type of use for a product, consumers - as Dick Hebdige showed in the case of the Italian motor scooter - may use things differently. ${ }^{50}$ Mass culture incorporates subcultures in two ways, the commodity form (through mass production of dress, music etc,. and the ideological form, through the power exerted by bodies such as the police to condition and control behaviour. Stuart Hall's model of encoding/decoding, [Fig. 6], which suggests that television is constructed according to a series of codes, which are decoded by viewers, was applied to design by Tony Fry thus:

Design is essential in the economic and cultural production (the encoding) of our world as well as in its economic and cultural consumption (the decoding). These two moments are not separate poles, they are, in fact, brought together all the time, they exist in relation to each other and in the same moment. ${ }^{51}$

Following Hall, US anthropologist Grant McCracken's 1986 essay 'Culture and Consumption: A Theoretical Account of the Structure of Movement of the Cultural Meaning of Goods' [Fig. 7] (reproduced as 'the linchpin' of his book Culture and Consumption in 1988) argued for three locations of meaning, 'the culturally constituted world, the consumer good and the individual consumer as well as two moments of transfer: world-to-good and good-to-individual'. ${ }^{52}$ World-togood is equivalent to Hall's encoding, and good-to-individual is equivalent to Hall's decoding. As well as illuminating the importance of the consumer, McCracken's work is useful as a way of reflecting on the role of channels of mediation in contributing part of the meaning that exists prior 
to the transfer of meaning from good to individual consumer, tailored to designed goods rather than the TV broadcasts of Hall's model. Design historians were further influenced in their study of consumption by studies of advertising, including Stuart Ewen's Captains of Consciousness, the work of Judith Williamson and continued cultural studies such as Mica Nava, Andrew Blake, Iain MacRury and Barry Richards' Buy This Book..$^{53}$

Notwithstanding the work of feminist scholars including Angela McRobbie, British cultural studies has been criticised for focussing on male working class consumption, a point which JeanChristophe Agnew, in his useful review of work on consumption, compared with Colin Campbell's emphasis on consumption as an expression of middle class longing. ${ }^{54}$ And gender analyses have illuminated our understanding of production, consumption and their interface ${ }^{55}$ Fry recognises that 'Opposition to design as a concept neatly divided between production and consumption ${ }^{56}$ has included the critique mounted by feminist scholars. Fry cites Dolores Hayden's The Grand Domestic Revolution, but Ruth Schwarz-Cowan's More Work for Mother is also exemplary here. ${ }^{57}$ Feminist design historians have been instrumental in the consumption turn within design history. An emphasis on consumption in design history allows recognition of the roles of women, who have not only been excluded more or less formally from various design professions, but have also operated to shape the history of design in ways different to men. The late Judy Attfield and Pat Kirkham's anthology A View from the Interior is just one example of scholarship which, along with considering women's role as designers, also considers how objects, such as the stiletto heel, have been consumed. ${ }^{58}$

Anthropology has been useful to design historians examining consumption, including notably Mary Douglas and Baron Isherwood's The World of Goods: towards an anthropology of consumption (1979) and the work of Daniel Miller. ${ }^{59}$ Despite having criticised design history in 1987 as ‘bizarre.... form of pseudo art history', the work of anthropologist Daniel Miller has been 
especially useful for design historians considering consumption. ${ }^{60}$ Alison J. Clarke quotes directly from Miller in concluding her book Tupperware: the Promise of Plastic in 1950s America:

Artifacts are bound by complex and interactive social contexts; their consumption is not merely a market-driven response to values of production. The constraints and interests of commerce, profit, manufacturing, design, advertising, and marketing are inseparable from broader discourses of consumption, through which consumers "manipulate the meanings of ...forms through differential selection, placement, use and association." 61

The work of the late Judy Attfield is also notable for the design historical application of anthropological and ethnographic techniques of research and analysis. ${ }^{62}$ In 'reviewing the relationship between material culture and design history', she reflected in 1999: 'In the last twenty years consumption studies has grown from a precocious intruder to become an essential ingredient in the understanding of the history of design.' She cites Christopher Breward's The Culture of Fashion and Penny Sparke's As Long As It's Pink and Jonathan Woodham's Twentieth Century Design as examples of the reach of a concern for consumption. ${ }^{63}$ Attfield goes on: A material culture approach in the study of the history of design [...involves...] investigating the history of design primarily for what it can reveal about the social meaning of things, rather [than] from the more usual judgemental, functional or aesthetic standpoint [... This is] dangerous for those who still see themselves as guardians of 'good design'. ${ }^{64}$

Design historical understanding of consumption has drawn on studies in social, cultural and economic history such as Neil McKendrick, John Brewer and J. H. Plumb's The Birth of a Consumer Society (1982) and John Brewer and Roy Porter's 1993 edited collection Consumption and the World of Goods, which examined the development of consumer society in the seventeenth and eighteenth centuries. ${ }^{65}$ Economist Ben Fine and Ellen Leopold have pointed out the difficulty of adequately addressing consumption:

...how complex and varied are the factors involved in consumption. There are the economic variables of price and income, sociological variables of family and status, psychological variables of motivation and habit, cultural variables of tastes and meaning, and not least the practical variables surrounding the actual activities of shopping, preparation, disposal or even repair. It is inconceivable that any one general theory of consumption will suffice. ${ }^{66}$ 
Furthermore, Fine and Leopold note: 'The lack of any substantial consensus in basic concepts inhibits the progressive development of a truly interdisciplinary (as opposed to a multidisciplinary) approach':

It is not simply the co-existence of mutually exclusive explanatory factors; the definition of the subject itself differs markedly from one discipline to the next. [...] For some it is a ritual, for others a means of class distinction and status, a means of satisfying utility or broader psychological impulses, etc. Within economics, consumption tends to be associated with movements of or along demand curves; in advertising and some of the work on material culture, it concerns the creation of real or imaginary lifestyles through the reconstruction of our objects of desire. As display, consumption can be the means of exercising as well as of enjoying power... ${ }^{67}$

While the interdisciplinary nature of design history has been recognised by design historians as a positive characteristic, according to Fine and Leopold's argument, it is the failure to achieve fully formed interdisciplinarity which has impeded the study of consumption. More recently, the study of globalisation has been of benefit to understanding consumption both within and without Western capitalism. ${ }^{68}$ Design history's promiscuity, in terms of using material and methods from other disciplines, has served it well; design history makes pragmatic use of work from outside the discipline. But this is not the same as working with scholars in other disciplines to produce interdisciplinary outcomes which might lead to greater understanding of consumption processes.

Julier and Narotsky have applied the ideas of Fine and Leopold design history, questioning the definition of consumption applied by design historians, and suggesting that it was neither sufficiently definite, not sufficiently dynamic:

...is it at the moment of decision making about acquisition, the point of sale, use and reuse? This criticism isn't about academic pedantry, it is about a refusal to come to terms with the questions raised by making that definition. It maintains a myth of consumer empowerment and avoids considering consumer interactions with production values. It avoids acknowledging the possibility that consumption is never static on the vertical axis of systems of provision, that consumption takes place at different points, often at different levels, in the life of products. ${ }^{69}$

Julier and Narotsky's critique appears to derive from a sense of frustration that consumption studies in design history have not gone further, rather than from disaffection for the issues 
involved, because they acknowledge the study of consumption as 'an important countermovement in design history' and a 'sub-discipline [which] seeks to understand the experience and meaning of design objects among their users. ${ }^{, 70}$

An emphasis on consumption has both enjoyed a period of prominence and been a continuing aspect of the design historical project. To study designers tells only one side of the story, but to study consumers can equally run the risk of privileging one dimension. Design history is sufficiently flexible to accommodate a range of approaches and interests so that studies which begin with the designer or the manufacturer as a focal point co-exist alongside those which ask questions about users and studies which are interested in production and consumption and their interface through processes of mediation.

\section{III - The Mediation Emphasis: Design History's Three-Pronged Third Stream}

The application of cultural theory to the design historical project from the 1980s onwards shaped design history's narrative concerns and interpretative methods and informed an emphasis on mediating processes in the understanding of design. The consumption turn, which flourished in the 1990s and has continued as an important stream within design history since then, fed directly into the critical mass surrounding issues of mediation. To study mediation is to study the phenomena which exist between production and consumption, as being fundamentally important in inscribing meanings for objects.

Fry made a very early articulation of the significance of mediation as a focus for design history;

...the history of the mediation of a product - how, for example, it has been written about, illustrated, photographed, displayed, advertised - is also not only of historical interest but embedded in the formation of meaning. There is, of course, a relation of use and mediation, for instruction in use always occurs through the mediation of an instructor, instruction book, advertisement. The place of use and the user are also partly specified by mediation. $^{71}$ 
He concludes that 'A history of design should, therefore, be a history of formations and processes, as well as objects and form. ${ }^{72}$ Fry goes on to draw attention to the potential of the study of a specific form of mediation (consumer guidance such as instruction books and advertisements) for uncovering those who do not have a direct voice in the historical record:

Moreover, there are voices of those other than the producers of historical documents which one can encounter in such historical inquiry. The voices may belong to people who are workers, users, promoters, analysts. These people, especially if they are women (who are often neglected in written history) assert their presence through absence, unspoken utterance and in the form of the mediations of those who speak in their name. ${ }^{73}$

Clearly, reading mediating discourses which purport to speak to the experiences of, for example, women, demands careful treatment, with sensitivity to what may be inferred from such sources and what may not. ${ }^{74}$

Mediation offers a third stream which brings together issues of production and consumption, not through the examination of designers' intentions or actual consumption practices, but rather through the analysis of the cultural and social significance of designed objects, spaces and processes to reveal shared ideas and ideals. Within the PCM paradigm, the term 'mediation' encompasses at least three mutually constitutive phenomena: first, the mediation emphasis continues the consumption turn within design history by exploring the role of channels such as television, magazines, corporate literature, advice literature and so on in mediating between producers and consumers, forming consumption practices and ideas about design; second, the mediation emphasis examines the extent to which mediating channels are themselves designed and therefore open to design historical analysis - indeed, these channels have increasingly constituted the design historian's object of study (representative work of this kind is examined below); third, the mediation emphasis investigates the role of designed goods themselves as mediating devices - designed objects mediate between producer and consumer, just as they are used to mediate relations between individuals. In sum, the 'mediation' in the PCM paradigm 
refers to the study of the mediation of design and the channels through which this occurs, and the study of design as mediation.

\section{Mediating Channels as Evidence}

It is stating the obvious to point out that the historical record comprises a huge range of objects and images, from the pot shards uncovered in archaeological digs, to probate inventories, oil paintings, and, latterly, emails. Some such sources of evidence are primarily textual and some primarily visual or material. Yet, the analytical skills necessary to extract historical value from visual and material sources, which are the stock-in-trade of the design historian, are not adequately addressed in the output and education of mainstream historians. Visual analysis is important not only for design history but also for history more broadly, yet the visual and material aspects of the documentary sources which form the bulk of the evidence for historical writing have often been neglected and mainstream history has been based largely on the interpretation of words. That is why a relatively uncommon foray into objects analysis, such as American historian Laurel Thatcher Ulrich's Age of Homespun (2001), still needs to articulate the value of things as evidence and as worthy of historical investigation. ${ }^{75}$ This is the case even though material culture studies in its North American variety has made an extended examination of the use of objects in writing history, in titles such as Material Culture and the Study of Everyday Life (1978), History from Things: Essays on Material Culture (1993), and Learning From Things: Method and Theory of Material Culture Studies (1998). ${ }^{76}$ That the situation is changing is exemplified by the publication of new teaching materials such as History Beyond the Text: A Student's Guide to Approaching Alternative Sources (2008) and Karen Harvey's edited collection History and Material Culture: A Student's Guide to Approaching Alternative Sources (2009). ${ }^{77}$

The PCM paradigm demonstrates the variety of work undertaken within design history, but, stereotypically, design history situates the object as the focal point of analysis and finds out about 
it through a variety of sources be they visual, oral or - predominantly - textual. Yet, design historians already have the historiography, methodology and curricula needed to go beyond the use of visual and material sources as historical evidence to the focal analysis of such objects.

\section{Mediating Channels as the Object of Design Historical Analysis}

In addition to the influences discussed above, the consumption phase of design history drew on a growing body of theories of post-modernism in the arts which developed and gained influence from the 1970s onwards, building on post-structuralist concepts of play and ambiguity. ${ }^{78}$ Interest in mediation is both a logical extension of the consumption phase of design history, and bears the influence of a parallel concern for mediation in cultural studies which has drawn on the theories of Bourdieu, Benjamin and Debord. ${ }^{79}$ Baudrillard's 'ecstasy of communication' is one particularly vivid and provocative example that declared, in a 1983 reference to his own 1968 book, 'There is no longer any system of objects. ${ }^{80}$ Baudrillard's work has been taken up by, for example, John Thackara in 'Beyond the Object in Design', which discusses the implications of a postmodern, experiential model of design. This essay introduces Design after Modernism: Beyond the Object (1988), a book which establishes the roots of postmodern ideas in modernist design theory and contains a translation by Penny Sparke of text from Baudrillard's 1968 The System of Objects. ${ }^{81}$ As well as informing the design historical study of consumption, this theoretical material has supported an interest in discourse, based partly on the huge influence within cultural studies of Michel Foucault. ${ }^{82}$

Analysis of mediating discourses illuminates the false distinction between public and private as they occupy what Frankfurt School theorist Jurgen Habermas's termed 'the public sphere', described by historian Geoff Eley as:

... a sphere which mediates between society and state, in which the public organizes itself as the bearer of public opinion... the public sphere presumed the prior transformation of social relations, their condensation into new institutional arrangements, and the 
generation of new social, cultural and political discourse around this changing environment. $^{83}$

Writing in 1974, Habermas made clear the role of mediating discourse in the public sphere:

In a large public body this kind of communication requires specific means for transmitting information and influencing those who receive it. Today newspapers and magazines, radio and TV are the media of the public sphere. ${ }^{84}$

Bourdieu, particularly, is noted for articulating the work of cultural intermediaries. In his extensive 1979 study Distinction, he cites not only 'all the occupations involving presentation and representation (sales, marketing, advertising, public relations, fashion, decoration and so forth)' and 'all the institutions providing symbolic goods and services' (such as the medical profession), 'and in cultural production and organisation (youth leaders, play leaders, tutors and monitors, radio and TV producers and presenters, magazine journalists)' but also 'the art craftsmen in the old sense - upholsterers, wrought-iron workers, cabinet-makers, picture-framers, goldsmiths, jewellers, gilders or engravers,' who have been joined since the 1960s by 'makers of jewellery, printed fabrics, ceramics or hand-woven clothes. ${ }^{85}$ Bourdieu thus recognises the importance of designers and makers as cultural intermediaries. Notwithstanding his recognition of the significance of cultural intermediaries, or 'legitimizing agencies,' and his influence on studies of mediation, Distinction is not a study of those forces. It remains - tantalisingly - a study of taste, which used a questionnaire to explore respondents' consumption choices and practices, and the effects of various familial and scholastic, class and capital differences. ${ }^{86}$ Bourdieu's influence might be discerned, although it is not made explicit, in studies of design intermediaries such as business historian Regina Lee Blaszczyk’s Imagining Consumers: Design and Innovation from Wedgwood to Corning (2000). ${ }^{87}$

In their introduction to a 2002 special issue of Cultural Studies that asked 'Who Needs Cultural Intermediaries?' Sean Nixon and Paul du Gay recognise Bourdieu's seminal role in the study of 'cultural intermediaries' and call for more specific work to be done than is allowed by Bourdieu's 
inclusive definition. ${ }^{88}$ Their summary of the benefits of an emphasis on cultural intermediaries for cultural studies may be applied to design history and the gains for the discipline of a focus on mediation:

They force, on the one hand, an opening up of the arena of cultural circulation, which has been poorly studied within cultural studies. In particular, in relation to the study of the commercial domain and commercially produced culture, they shift our attention away from the over-emphasis on the moment of consumption that has tended to dominate recent accounts of the commercial field. In doing so, they open up the links between production and consumption and the interplay between these discrete moments in the lifecycle of cultural forms. More than that, by focusing on both the formal expertise and broader intellectual and cultural formation of these practitioners, it becomes possible to scrutinize the links between economic and cultural practices within the sphere of commercial cultural production; a scrutiny that can bring to light, as we have argued elsewhere, the interdependence and relations of reciprocal effect between cultural and economic practices. ${ }^{89}$

In the same issue of Cultural Studies, however, Keith Negus's case study of record and film executives criticises other work on cultural intermediaries for failing to bridge the gap between production and consumption by reproducing existing meanings, in an excluding way, rather than creating new interpretations. ${ }^{90}$ The work of what Liz McFall, in the same special issue, has called 'the old cultural intermediaries', advertising, has been a preoccupation among design historians including Judith Williamson. ${ }^{91}$ While Nixon and Du Gay wish to promote examination of the practice of cultural imtermediary professionals, design history can contribute analyses of artefacts as cultural intermediates and mediating channels.

Design history has displayed a long-standing interest in the analysis of mediating channels, as shown in a collection of student writing, undertaken over a period of almost twenty years, Design and the Modern Magazine, edited by Jeremy Aynsley and Kate Forde. ${ }^{92}$ The book's arrangement to demonstrates three strands of the study of the magazine: 'The magazine as a design object', 'magazines and the consumer', in which three essays examine the consumer education function of magazine editorial and advertising and the politics of magazine representations and 'promoting design through magazines'. The editors' introduction considers not only the utility of magazines 
as a resource for design historical understanding, but also the specific strengths of a design historical analysis of magazines. 'Unlike design history,' they note, 'cultural studies rarely engages with the circumstances of production, the design process or the material qualities of the magazines'. The essays in their book exemplify the strengths of design historical analysis.

The AHRB Centre for the Study of the Domestic Interior (2001-6) brought together scholars from literature, history and design history to produce a range of outcomes which use textual sources to understand designed goods and spaces in a sophisticated hybrid. One such is Publishing the Modern Home: Magazines and the Domestic Interior 1870-1965, a special issue of this journal edited by Jeremy Aynsley and Francesca Berry (2005). ${ }^{93}$ An important distinction can be made between studies which use magazines, for example, as evidence in the understanding of design and studies such as those showcased in Aynsley and Berry's special issue which look at magazines rather than through them; magazines themselves become the objects of study. Other studies include Ellen Mazur Thomson on graphic design periodicals, Jill Seddon's close reading of the relationship between writer and editor at Design magazine, Susan Sellers' treatment of Harper's Bazaar, Barbara Usherwood's analysis of Elle Decoration, both Dick Hebdige and Paul Jobling's writing on The Face, and Jennifer Scanlon's work on the Ladies' Home Journal. ${ }^{94}$

Other design historical studies of mediation range from analysis of litigation over the cantilever chair and consideration of how we understand graphic design through video oral history. ${ }^{95}$ Each of these analyses takes as its central focus a type of mediating discourse, whether legal records or designers speaking on film, and is as sensitive to the particular characteristics, constraints and affordances of the given medium as it is to what is told through that medium about design practice. Michelle Jones' work on the BBC's post-war design broadcasting and Jenny Tobias's analysis of US news broadcasting each offer contextualised accounts of the role of television in 
forming ideas of design, and the role of design in forming the televisual experience. ${ }^{96}$ A range of studies of design exhibitions are surveyed in The Modern Period Room; other related analyses include Deborah Ryan's work on the Ideal Home Exhibition and Monica Obniski's analysis of Gilbert Rohde's Design for Living Interior at the Chicago World's Fair, to name just a few examples. ${ }^{97}$ Emma Ferry's study of Rhoda and Agnes Garrett's Suggestions for House Decoration (1876) and Penny Sparke's work on Elsie de Wolfe have shown the utility of biographical approaches to advice discourse. Ferry's meticulous article offers an empirical case study of a mediating discourse - the advice book and, particularly, the Garretts' House Decoration - set within useful methodological reflection. Ferry tells us not only about a most interesting and significant advice book, but also about how it should be used by design historians. Through close reading, Ferry produces observations and conclusions which could not have been achieved with reference to any other material. The article is exemplary of the usefulness of design history's mediation phase. My own work on domestic advice literature has argued for an analytical focus on the mediating sources themselves as worthy of narrative analysis, rather than simply being used as historical evidence. ${ }^{98}$

\section{Mediation and the Biography of Things}

It is worth comparing this three-pronged account of how mediation can be a useful focus within design history with other useful approaches centred upon the object, in addition to the production focus and consumption focus already discussed. Mediation has been studied as part of a chain, or continuum of the object's lifecycle, as Julier and Narotsky have noted:

Fine and Leopold address design in terms of 'systems of provision', looking at the interactions which take place along the axis of consumption, production, mediation and use. This tracing of material and visual culture along a vertical axis from production to consumption, from origination, organisation and processing to social meaning, is one increasingly adopted by other sociologists such as Chaney (1996), [and] Lash and Urry $(1996){ }^{99}$ 
Another example is Igor Kopytoff's 'cultural biography of things' approach, outlined in an essay published in 1986. Here, Kopytoff elegantly outlines the extent to which meanings generated for objects by the market and society at large are negotiated by the individual, who imbues objects with different meanings in a continual process. He proposes that: 'An eventful biography of a thing becomes the story of the various singularizations of it, of classifications and reclassifications in an uncertain world of categories whose importance shifts with every minor change in context. ${ }^{100}$ Anthropologist Kopytoff does not address his text specifically at design historians, and the volume in which it appears is targeted at 'anthropologists, social historians, economists, archaeologists, and historians of art' according to the back cover. Nevertheless, the biographical approach he proposes is of interest to design historians, and - like the focus on mediation discussed here - has the potential to bridge production and consumption. Kopytoff positions his approach in opposition to Marx's emphasis on production, arguing instead that 'some of the power is attributed to commodities after they are produced, and this by way of an autonomous cognitive and cultural process of singularization' ${ }^{101}$ Kopyoff proposes that a biographical approach be based on a number of compelling questions to be asked of objects:

In doing the biography of things, one would ask questions similar to those one asks about people: What, sociologically, are the biographical possibilities inherent in "status" and in the period and culture and how are these possibilities realized? Where does the thing come from and who made it? What has been its career so far, and what do people consider to be an ideal career for such things? What are the recognized "ages" or periods in the thing's "life", and what are the cultural markers for them? How does the thing's use change with its age, and what happens to it when it reaches the end of its usefulness? ${ }^{102}$

Attributing to an object the agency necessary for it to have a 'career' is a useful, and artificial, scholarly position designed to illuminate the place of the object within social context. Kopytoff distinguishes between the biographies of things in complex and small-scale societies:

Thus, the economies of complex and highly monetized societies exhibit a two-sided valuating system: on one side is the homogenous area of commodities, on the other, the extremely variegated area of private valuation. [...] The result is a complex intertwining of the commodity exchange sphere with the plethora of private classifications, leading to anomalies and contradictions and to conflicts both in the cognition of individuals and in the interaction of individuals and groups. ${ }^{103}$ 
The value of the biographical approach, as part of a mediation focus, is as a tool or set of questions which can elucidate the relationship of the object to both the public "commodity exchange sphere' and the private sphere, or - to put it another way - the production sphere and the consumption sphere. Because the meanings of objects are seen by Kopytoff to be forged by what we might term the production and consumption spheres, objects offer the researcher a route to understanding the society in which the object operates. This object-centred approach is therefore related to the third prong of the mediation focus outlined in this article, the way in which objects themselves can be regarded as being imbued with a mediating function, mediating between self and society. The study of mediation, if interpreted solely as the study of mediating discourses, can only tell us a limited amount about what an object might mean to a consumer. Private meanings might not be represented in the public discourse of mediation. However, if the processes and artefacts of mediation are viewed as bridging production and consumption, then their study can be shown to inform understanding of both of these phenomena. Design historians are preeminent explorers of the mediating function of objects, using the range of available methods to explore the design, manufacture, consumption and, yes, mediation, of these mediating artefacts. The mediating function of objects has not, as yet, received sufficient scholarly attention and a great deal of potential for further work exists both here and in the narrative capacity of objects.

\section{Conclusion: Production + Consumption + Mediation}

The PCM paradigm within design history may be associated with a shift away from object-based analyses in favour of broader analyses of the cultural meanings of artefacts. By 'object-based analysis' I mean close first-hand examination of individual objects and groups of objects, and the placement of the object as the central focus through examination of its design, manufacture and use. This is akin to a combination Walker's 'materials/techniques approach' and 'typological approach', along with several of the categories discussed in his chapter 'Designers and Designed Goods - the Proper Objects of Study? ${ }^{104}$ 
In 1998, Meikle provided a cautionary tale of what happens when design historians neglect to engage with objects and stay, instead, in the realm of representation. Meikle explains how he believed a story promoted by Henry Dreyfuss about a plug of iron being inserted into his Big Ben alarm clock to make it weightier, until he opened up his own clock and found no weight inside. ${ }^{105}$ He urges design historians not to take documentary and pictorial sources at face value; projected theories about the meanings of design need to be tested through first hand examination.

In the same year, Julier and Narotsky claimed provocatively that design historians 'are dangerously out of touch with the activity they seek to analyze. This nomadic tribe has wandered so far from its roots that we question whether design history has made itself redundant as a contributor to paradigms of practice. ${ }^{, 106}$ Julier and Narotsky celebrate design as 'a collaborative venture which is supremely interdisciplinary, in that it unites specialists in two and threedimensional communication, visual and material culture, and it is interdisciplinary in that it brings different domains together.' ${ }^{107}$ The same can surely be said of design history, yet Julier and Narotsky castigate what they call design history's nomadism. They ask 'design history to return to its roots and bed itself with practice. And in so doing, the fascinating, reflexive nature of design will be revealed.' This view assumes that design history is a parasitic activity that is led by its host, design, and risks ironically denying the former the agency needed to make a difference in the way that Julier and Narotsky demand. 'In short,' Julier and Narotsky proclaim, 'design practice both as a field of academic enquiry and as a profession has outstripped the paradigms and critiques of design history. ${ }^{108}$ Rather than measuring design history by the yardstick of design, surely it is more accurate to conceive of design history as something which can be useful for designers but which also has its own disciplinary aims, concerns and achievements? Design historians write for designers, but shouldn't it be accepted that we might also find it useful to 
write for each other and other historians? Why pit practice and design history against one another as though they were competing, rather than collaborating?

For some, the mediation emphasis may imply a move away from the object as the unit of study and a shift from design history to cultural history. Cultural history and design history have much in common and a number of key texts used by design historians derive from cultural history. However, like Jonathan Woodham, Nigel Whiteley has called for valuing what is distinctive about design history in a considered response to the design studies/design history debate:

Cultural studies writing also suffers too often from visual insensitivity, and reveals an inability to make fine visual discriminations perhaps not surprisingly when most of its exponents have had no visual education. So I would say take on the ideas from cultural studies, because they open up greater possibilities for understanding design; but try to maintain design history's clarity and directness of communication, and visual sophistication. ${ }^{109}$

Design historians have demonstrated a particular blend of expertise centred upon a holistic understanding of the significance of objects and images within our culture, past and present. But equally, the interdisciplinary flexibility of design history may be seen as necessary to its continued health, rather than signalling its disappearance, and we have much to contribute to associated disciplines.

Far from moving design history away from what has been our distinctive expertise into the more general arena of cultural history, or heralding the demise of a discrete identity for design history, a concern for mediation enables richer understanding of, and focal concern for the object. The material world is an outcome of social needs and desires, and the material and social worlds are mutually constitutive. The mediation focus enables recognition of the fact that design is much more than the object; it is a complex web of surrounding practices and discourses. Tony Fry's 1988 study Design History Australia has been cited extensively in the article as an incisive and 
prescient account of the discipline which anticipated much of the scholarship of the decades since its publication. Fry reminds us that:

...we usually proceed on the basis of the existence of an object as a material essence. However, we never know objects as purely material. Objects exist in sign systems, in language, thus they are coded - to know them and to speak of them they have to exist, in some form, in our imagination before a material encounter. ${ }^{110}$

To view the study of design in this way is not to efface the importance of the object, or of object analysis, but rather to maintain those emphases while also adding others which enrich the practice and output of design history. A magazine is a channel of mediation, but it is also an object in its own right. Television has a significant physical and material presence in our homes, as well as serving as a route into our worlds for advertisers, manufacturers, entertainers, educators and so on. ${ }^{11}$ Furthermore, a binary distinction between the material and the social, between the object and surrounding mediating channels, is artificial when the two are mutually constitutive, as shown in the best design historical analysis. If we can explore the ways in which channels of mediation create meaning for designed goods and design processes, and remain attentive to object analysis, so that design is not obscured by its own surrounding discourses, we will enrich an embedded understanding of how designed objects operate as mediating elements themselves within social practices. David Raizman's History of Modern Design is one example of a text which goes some way towards integrating the production, consumption and mediation emphases. ${ }^{112}$

A generation after Dilnot's 1984 call for 'socio-historical understanding', we can see his plea prefigured a swathe of contextualised design history which followed. While there is no cause for complacency, Dilnot's 1984 complaint about the 'general lack of historical, methodological, or critical self-reflection' can no longer be levelled at this most interdisciplinary, flexible and fascinating of disciplines. The future of design history may depend on the successful alignment of object-based understanding - the hallmark of design history - with analysis of socio-historical 
contexts. While the production and consumption emphases within design history are wellrecorded, the mediating role of designed objects and processes and the potential of the study of design as a mode of mediation to shape new directions in design history have yet to be fully exploited. This article has identified a production-consumption-mediation paradigm, and a discussion of its methodological and interdisciplinary implications. It is hoped that this contribution, and the account of mediation supplied here, will stimulate further discussion and scholarship. Informed by existing and current studies oriented around production or consumption, mediation has the potential to provide a rich analytical category for future work in design history. 
1 J. A. Walker, Design History and the History of Design, Pluto Press, London, 1989, p. 68.
2 Walker, 1989 , p. 69.
${ }^{3}$ This article is developed from a paper, 'Mediation: From Design History to Cultural History?' delivered at ${ }^{3}$ This article is developed from a paper, 'Mediation: From Design History to Cultural History?' delivered at
the College Art Association 96th Annual Conference, Dallas Fort Worth, USA, 20-23 February, 2008. For an earlier, brief, articulation of this idea, see G. Lees-Maffei, 'Introduction: Studying Advice: Historiography, Methodology, Commentary, Bibliography', Journal of Design History, vol. 16, no. 1 (2003), pp. 1-14, p. 3 and G. Lees-Maffei, Modern Living? Domestic Advice Literature and Design Discourse in Post-War Britain, Upublished PhD thesis, University of Portsmouth, 2005, pp. 10-18. Thanks to anonymous reviewer 6 for detailed and helpful comments on an earlier draft of this article.

${ }^{4}$ A detailed review of the literature of design history was conducted by the author for the purposes of this article and in preparing The Design History Reader, ed. G. Lees-Maffei and R. Houze, Berg, Oxford, 2010. ${ }^{5}$ I. Kopytoff, Igor, 'The Cultural Biography of Things: Commoditization as Process', in A. Appadurai, ed., The Social Life of Things: Commodities in Cultural Perspective, Cambridge University Press, Cambridge, 1986, pp. 64-91, p. 90.

${ }^{6}$ R. Barthes, 'The Death of the Author', pp. 142-8, and 'From Work to Text', pp. 155-164, in ImageMusic-Text, trans. S. Heath, Fontana, London, 1977; H. White, Metahistory: the Historical Imagination in Nineteenth Century Europe, Johns Hopkins University Press, Baltimore and London, 1973.

${ }^{7}$ Walker, 1989, p. 70.

${ }^{8}$ Consideration here of the distinctions between diachronic and synchronic methods is informed by Structuralist approaches to the study of culture based on Ferdinand de Saussure's Course in General Linguistics of 1915, in which he argued for the utility of studying language as a system of relations, as distinct from existing concern for the historical development of language. For influential applications of synchronic approaches to cultural analysis See Barthes, 1977, and R. Barthes, Mythologies, trans. A. Lavers, Jonathan Cape, London, 1972 (Editions du Seuil, Paris, 1957).

${ }^{9}$ T. S. Kuhn, The Structure of Scientific Revolutions, University of Chicago Press, Chicago and London, 1962; T. S. Kuhn, 'Reflections on my Critics', in Imre Lakatos and Alan Musgrave, eds. Criticism and the Growth of Knowledge, Cambridge University Press, Cambridge, 1970, pp. 231-278.

${ }^{10}$ E. Guba, ed. The Paradigm Dialog, Sage, London, 1990, p. 17. Guba refers to M. Masterman, 'The Nature of a Paradigm', in Imre Lakatos and Alan Musgrave, eds., 1970, pp. 59-89. Guba's approach has been critiqued by, for example, M. Hammersley in 'Review: The Paradigm Wars: Reports from the Front', British Journal of Sociology of Education, vol. 13, no. 1 (1992), pp. 131-143.

${ }^{11}$ C. Dilnot, 'The State of Design History Part I: Mapping the Field', Design Issues, vol. 1, no. 1 (1984a), pp. 3-23; V. Margolin, 'Design History and Design Studies', Design Studies, vol. 13, no. 2 (1992), pp. 104116 reprinted in Design Issues, vol. 11, no. 1 (1995), pp. 4-15 and in The Politics of the Artificial: Essays on Design and Design Studies, University of Chicago Press, Chicago, 2002, pp. 218-233; J. M. Woodham, 'Resisting Colonization: Design History Has Its Own Identity', Design Issues, vol. 11, no. 1 (1995), pp. 2237; G. Julier and V. Narotsky, 'The Redundancy of Design History', paper presented to the conference 'Practically Speaking', Wolverhampton University, December 1998, and published at Design Observatory, occasional papers, Leeds Metropolitan University, http://www.Imu.ac.uk/as/artdesresearch/Projects/design_observatory/the redundancy of design history.ht $\underline{m}$ accessed 26/05/09.

${ }^{12}$ The British Ministry of Education published Sir William Coldstream's report for the National Advisory Council on Art Education in 1960 and in 1970, Coldstream and Summerson's The Structure of Art and Design Education in the Further Education Sector appeared. See J. M. Woodham, 'Local, National and Global: Redrawing the Design Historical Map,' Journal of Design History, vol. 18, no. 3 (2005), pp. 257267.

${ }^{13}$ P. Sparke, 'Introduction,' Design History. Fad or Function, Design Council, London, 1978, p. 5. See, for example, G. Naylor, The Bauhaus, Studio Vista, London, 1968 and The Arts and Crafts Movement: a Study of its Sources, Ideals and Influence on Design Theory, Studio Vista, London, 1971.

${ }^{14}$ This quotation is from the Society's mission statement which has since been re-worded in a longer and more inclusive form, as per the website www.designhistorysociety.org consulted 01/01/2008.

${ }^{15}$ N. Pevsner, Pioneers of the Modern Movement, Faber \& Faber, London, 1936; second edition Museum of Modern Art, New York, 1949; revised edition, Pioneers of Modern Design: from William Morris to 
Walter Gropius, Pelican Books, London, 1960, revised 1975. It is not within the remit of this article to explicate or mount a critique of Pevsner's work; his influence upon a certain tendency within design history is simply being noted. Existing published discussion of Pevsner's work and its influence includes Peter Draper, ed., Reassessing Nikolaus Pevsner, Ashgate, Aldershot, 2004 and P. Madge, 'An Enquiry into Pevsner's Enquiry', Journal of Design History, vol. 1, no. 2, (1988), pp. 113-126.

${ }^{16}$ S. Bayley, In Good Shape: Style in Industrial Products, 1900 to 1960, Design Council, London, 1979; D. Sudjic, Cult Objects, Paladin, London, 1985.

${ }^{17}$ Bayley, 1979, Lord Reilly, 'Foreword', p. 9, 'Preface', p. 12.

${ }^{18}$ Sudjic, 1985 , p. 23 , p. 159.

${ }^{19}$ Museum of Modern Art, Machine Art, sixtieth anniversary edition, The Museum of Modern Art, New York, 1994 (1934), Cat. No. 26, 'Section of wire rope $3 \frac{1}{2}$ '” in diameter. American Steel and Wire Co., Subsidiary United States Steel Corp.' and Cat. No. 117 'Crusader hotel ladles, Lalance and Grosjean Mfg. Co., $\$ 1.08$ to $\$ 4.45$ '; Cat. No. 50, 'Self-aligning ball bearing. S.F.K. industries' also on cover, n.p.

${ }^{20}$ T. Smith, 'Pure Modernism, Inc.', Making the Modern: Industry, Art and Design in America, University of Chicago Press, Chicago and London, 1993, p. 394.

${ }^{21}$ T. Fry, Design History Australia, Hale \& Iremonger, Sydney, Australia, 1988, pp. 21-27.

${ }^{22}$ R. Banham, Theory and Design in the First Machine Age, The Architectural Press, London, 1960; J. L. Meikle, 'Material Virtues: On the Ideal and the Real in Design History', The Journal of Design History, vol. 11, no. 3, (1998), pp. 191-199, pp. 192-3.

${ }^{23}$ N. Whiteley, 'The Puzzled lieber Meister: Pevsner and Reyner Banham', in Draper, ed., 2004, pp. 213235; N. Whiteley, Reyner Banham: Historian of the Immediate Future, The MIT Press, Cambridge, MA, 2002.

${ }^{24}$ Julier and Narotsky, 1998, n.p.; Fry, 1988, p. 28.

${ }^{25}$ Julier and Narotsky, 1998, n.p.

${ }^{26}$ Fry, 1988, p. 74.

${ }^{27}$ Ibid, p. 75.

${ }^{28}$ Relevant methodological analyses of design history, not mentioned elsewhere in this article, are: T. Fry, 'Design History: a Debate?' in Block, no. 5 (1981), pp. 14-18; V. Margolin, 'A Decade of Design History in the United States 1977-87', The Journal of Design History, vol. 1, no. 1, (1988), pp. 51-72 revised and reprinted as 'Design History in the United States, 1977-2000', in The Politics of the Artificial: Essays on Design and Design Studies, University of Chicago Press, Chicago, 2002, pp. 127- 186; V. Margolin, 'Postwar Design Literature: a Preliminary Mapping', Design Discourse: History, Theory, Criticism, University of Chicago Press, Chicago and London, 1989, pp. 265-287; P. Pacey, "'Anyone Designing Anything?" Non-Professional Designers and the History of Design', The Journal of Design History, vol. 5, no. 3, (1992), pp. 217-225; J. Attfield, 'The Meaning of Design: Things with Attitude', Wild Things: the Material Culture of Everyday Life, Berg, Oxford, 2000, pp. 11-43.

${ }^{29}$ Dilnot, 1984a, p. 11, p. 12. See also C. Dilnot, 'The State of Design History Part II: Problems and Possibilities', Design Issues, vol. 1, no. 2 (1984b), pp. 3-20.

${ }^{30}$ V. Margolin, 'Design History and Design Studies: Subject Matter and Methods', Design Studies, vol. 13, no. 2 (April 1992), pp. 104-116.

${ }^{31}$ A. Forty, 'A Reply to Victor Margolin', The Journal of Design History, vol. 6, no. 2 (1993), pp. 131-132.

${ }^{32}$ A. Forty, Objects of Desire: Design and Society Since 1750, Thames and Hudson, London, 1986.

${ }^{33}$ Fry, 1988, p. 37.

${ }^{34}$ Design Issues, vol. 11, no. 1 (1995), including Woodham, 1995; V. Margolin, 'A Reply to Adrian Forty'; J. L. Meikle, 'Design History for What? Reflections on an Elusive Goal', pp. 71-75; A. Findeli, 'Design History and Design Studies: Methodological, Epistemological and Pedagogical Inquiry', pp. 43-65; D. Doordan, 'On History', pp. 76-81.

${ }^{35}$ For example, C. Dilnot, 'The Critical in Design (Part One)', Journal of Writing in Creative Practice, vol. 1, no. 2 (June 2008), pp. 177-190 and Writing Design: Object, Process, Discourse, Translation, the 2009 Design History Society Annual Conference, convened by G. Lees-Maffei and J. Kelly, and hosted by the tVAD Research Group, (University of Hertfordshire, 3-5 September 2009).

${ }^{36}$ M. Guyatt, 'The Wedgwood Slave Medallion: Values in Eighteenth-Century Design', The Journal of Design History, vol. 13, no. 2 (2000), pp. 93-105 and M. Guyatt, 'Better Legs: Artificial Limbs for British Veterans of the First World War,' The Journal of Design History, vol. 14, no. 4 (2001) pp. 307 - 325. 
${ }^{37}$ P. Sparke, Ettore Sottsass, Design Council, London, 1982; J. Heskett, Philips: a Study of the Corporate Management of Design, Rizzoli, New York, 1989 (Trefoil, London, 1989); T. Harrod, The Crafts in Britain in the $20^{\text {th }}$ Century, The Bard Graduate Center for Studies in the Decorative Arts and Yale University Press, New York, 1999.

${ }^{38}$ Attfield, Edwards and Breward have all published extensively. Among their books, see for example, J. Attfield, 'Good design by law: adapting Utility furniture to peacetime production - domestic furniture in the reconstruction period', pp. 26-36; 'Then we were making furniture, not money': a case study of J. Clarke, Wycombe furniture-maker', pp. 53-61 and 'Give 'em something dark and heavy': the role of design in the material culture of popular British furniture, 1939-65', pp. 97-119 in Bringing Modernity Home: Writings on Popular Design and Material Culture, Manchester University Press, Manchester, 2007; C. Edwards, Twentieth Century Furniture: Materials, Manufacture and Markets, Manchester University Press, Manchester, 1994; C. Breward, The Culture of Fashion: A New History of Fashionable Dress, Manchester University Press, Manchester, 1995. Each of the books mentioned here is part of the Studies in Design series, for which Breward is general editor.

${ }^{39}$ Forty, 1986, p. 8.Although Forty decries the glib use of the label 'social context', it is apt in describing what he has attempted in relation to design history in this book.

${ }^{40}$ Walker, 1989, p. 174.

${ }^{41}$ M. Hilton and M. Daunton, 'Material Politics: An Introduction', in The Politics of Consumption: Material Culture and Citizenship in Europe and America, ed. M. Hilton and M. Daunton, Berg, Oxford, 2001, pp. 1-32, p. 6.Reference is made to G. Debord, The Society of the Spectacle, Black and Read, Detroit, 1970 and J. Baudrillard, The Consumer Society: Myths and Structures, Sage, London, 1998. Further sociological approaches to consumption are discussed in P. Corrigan, The Sociology of Consumption, Sage, London, 1997 and C. Lury, Consumer Culture, Polity, Cambridge, 1996. Other examples of Hilton's work of relevance to design history include Consumerism in $20^{\text {th }}$-Century Britain, Cambridge University Press, Cambridge, 2003.

${ }^{42}$ Forty, 1986; P. Sparke, An Introduction to Design and Culture, 1900 to the Present, Unwin Hyman Ltd., London, 1986 and second edition, Routledge, London, 2004; Fry, 1988.

${ }^{43}$ Hilton and Daunton, 2001, p. 6.

${ }^{44}$ Bailey, Chris, 'Editorial', The Journal of Design History, vol. 1, no. 1 (1988).

${ }^{45}$ Barthes, 1972 (1957); Barthes, 1977 including, of particular relevance to design history, in addition to the essays already mentioned, 'The Photographic Message', pp. 15-31; 'Rhetoric of the Image', pp. 32-51; 'An Introduction to the Structural Analysis of Narratives', pp. 79-124.

${ }^{46}$ Walker, 1989 , p. 11, p. 16 , p. 58 , p. 61 , pp. $137-152$

${ }^{47}$ Forty, 1986, p. 9.

${ }^{48}$ See, for example, S. Hall and T. Jefferson, eds., Resistance through Rituals: Youth Subcultures in Postwar Britain, Hutchinson, London for the Centre for Contemporary Cultural Studies, University of Birmingham, 1976. For an analysis of the achievements of British Cultural Studies see G. Turner, British Cultural Studies: An Introduction, second edition, Routledge, London, 1996.

${ }^{49}$ R. Hoggart, The Uses of Literacy, Penguin, Harmondsworth, 1958; Hebdige, 'Subculture: the Unnatural Break,' and 'Two Forms of Incorporation,' in Subculture: the Meanings of Style, Methuen \& Co., London, 1979, pp. 92-99; D. Hebdige, 'Towards a Cartography of Taste 1935-1962,' Hiding in the Light: on Images and Things, Routledge, London, 1988, pp. 45- 76.

${ }^{50}$ D. Hebdige, 'Object as Image: the Italian Scooter Cycle' Block, no. 5 (1981), pp. 44-64, reprinted in Hebdige, 1988, pp. 77- 115. Cf. A. Arvidsson, 'From Counterculture to Consumer Culture: Vespa and the Italian Youth Market, 1958-1978', Journal of Consumer Culture, vol. 1, no. 1 (2001), pp. 47-71.

${ }^{51}$ Fry, p. 17. ; S. Hall, 'Encoding, Decoding', in The Cultural Studies Reader, ed. S. During, Routledge, London, 1993, pp. 90-103, first appeared as 'Encoding and Decoding in Television Discourse', CCCS Stencilled Paper no. 3, 1973 and was popularised through publication as 'Encoding/Decoding', in Culture, Media, Language: Working Papers in Cultural Studies1972-1979, ed. S. Hall, D. Hobson, A. Lowe and P. Willis, Routledge, London, 1980. pp. 128-38.

${ }^{52}$ G. McCracken, 'Meaning Manufacture and Movement in the World of Goods', Culture and Consumption: New Approaches to the Symbolic Character of Consumer Goods and Activities, Midland Book Edition, Indiana University Press, Bloomington and Indianapolis, 1990 (1988), pp. 71-89, p. 71. This was developed from an essay first published as 'Culture and Consumption: A Theoretical Account of the 
Structure and Movement of the Cultural Meaning of Consumer Goods', Journal of Consumer Research, vol. 13 (1986), pp. 71-84.

${ }^{53}$ S. Ewen, Captains of Consciousness: Advertising and the Social Roots of Consumer Culture, McGraw Hill, New York, 1976; J. Williamson, Decoding Advertisements: Ideology and Meaning in Advertising, Marion Boyars, London, 1978; M. Nava, A. Blake, I. MacRury and B. Richards, Buy This Book: Studies in Advertising and Consumption, Routledge, London, 1997.

${ }^{54} \mathrm{~J}-\mathrm{C}$ Agnew, 'Coming up for air: consumer culture in historical perspective', in J. Brewer and R. Porter, eds., Consumption and the World of Goods, Routledge, London, 1994 (1993), pp. 19-39. See C. Campbell, The Romantic Ethic and the Spirit of Modern Consumerism, Basil Blackwell, Oxford, 1987; A. McRobbie, Feminism and Yout Culture: From Jackie to Just Seventeen, Macmillan Education, Basingstoke, 1991.

${ }^{55}$ See Lees-Maffei, 2003, p. 2, n. 19.

${ }^{56}$ Fry, p. 42.

${ }^{57}$ D. Hayden, The Grand Domestic Revolution : a history of feminist designs for American homes, neighborhoods, and cities, MIT Press, Cambridge, Mass., 1981; R. S. Cowan, More Work for Mother: the ironies of household technology from the open hearth to the microwave, Basic Books, New York, 1983.

${ }^{58} \mathrm{~J}$. Attfield, and P. Kirkham, eds., A View from the Interior: Feminism, Women and Design, The Women's Press, London, 1989, and L. Wright, 'Objectifying Gender: the Stiletto Heel', pp. 7-19 in that volume.

${ }^{59}$ M. Douglas and B. Isherwood, The World of Goods: Towards and Anthropology of Consumption, bsic Books, New York, 1979, second edition Routledge, London, 1996.

${ }^{60}$ D. Miller, Material Culture and Mass Consumption, Basil Blackwell, Oxford, 1987, p. 142. Also, D. Miller, ed., Acknowledging Consumption: a Review of New Studies, Routledge, London, 1995 and within it 'Consumption as the Vanguard of History: a Polemic by Way of an Introduction', pp. 1-57.

${ }^{61}$ A. Clarke, Tupperware: the Promise of Plastic in 1950s America, Smithsonian Institution Press, Washington, 1999, p. 201. See also, A. J. Clarke, 'The Aesthetics of Social Aspiration', in D. Miller, ed., Home Possessions: Material Culture behind Closed Doors, Berg, Oxford, 2001, pp. 23-46.

${ }^{62}$ Attfield, 2000.

${ }^{63} \mathrm{~J}$. Attfield, 'Review article. Beyond the pale: reviewing the relationship between material culture and design history', Journal of Design History, vol. 12, no. 4 (1999), pp. 373-380, p. 373. Attfield refers to. Breward, 1995; P. Sparke, As Long As Its Pink, Pandora, London. 1995 and J. M. Woodham, Twentieth Century Design, Oxford University Press, Oxford, 1997.

${ }^{64}$ Attfield, 1999, p. 373.

${ }^{65}$ N. McKendrick J. Brewer and J. H. Plumb, The Birth of a Consumer Society, Europa, London, 1982; Brewer and Porter, eds., 1983.

${ }^{66}$ B. Fine and E. Leopold, The World of Consumption, Routledge, London, 1993, p. 4.

${ }^{67}$ Fine and Leopold, 1993, p. 6.

${ }^{68}$ In analysing the most prominent consumer nation, American studies and American history have been preoccupied with consumption; an introduction to some of this writing is given in L. B. Glickman's Consumer Society in American History: A Reader, Cornell University Press, Ithaca and London,1999. An example of a global study of consumption is Frank Trentman, ed., The Making of the Consumer:

Knowledge, Power and Identity in the Modern World, Berg, Oxford, 2006.

${ }^{69}$ Julier and Narotsky, 1998, n.p.

${ }^{70}$ Ibid.

${ }^{71}$ Fry, p. 12

${ }^{72}$ Ibid., p. 43.

${ }^{73}$ Ibid., p. 19.

${ }^{74}$ See Lees-Maffei, 2003 for a discussion of the uses of mediating discourse such as advice literature in the writing of design history.

${ }^{75}$ L. T. Ulrich, The Age of Homespun: Objects and Stories in the Creation of an American Myth, Alfred A. Knopf, New York, 2001; reviewed by G. Lees-Maffei, The Journal of Design History, vol. 15, no. 2 (2002), pp. 124-126.

${ }^{76}$ I. M. G. Quimby, ed., Material Culture and the Study of Everyday Life, W. W. Norton \& Company, Inc., New York, 1978; S. Lubar and W. D. Kingery, History from Things: Essays on Material Culture, Smithsonian Institution Press, Washington and London, 1993; W. D. Kingery, Learning From Things: Method and Theory of Material Culture Studies, Smithsonian Institution Press, Washington and London, 1998. 
${ }^{77}$ S. Barber, C. Preston-Bird, eds., History Beyond the Text: A Student's Guide to Approaching Alternative Sources, Routledge, London, 2008; K. Harvey, ed., History and Material Culture: A Student's Guide to Approaching Alternative Sources, Routledge, London, 2009.

${ }^{78}$ See H. Foster, ed. Postmodern Culture, Bay Press, Port Townsend, WA, 1983 and Pluto Press, London, 1985.

${ }^{79}$ P. Bourdieu, Distinction: A Social Critique of the Judgement of Taste, (1979) trans. R. Nice, Routledge and Kegan Paul, London, 1984; W. Benjamin, 'The Work of Art in the Age of Mechanical Reproduction', in Illuminations, ed. H. Arendt, Schocken Books, New York, 1968, pp. 217-252; G. Debord, The Society of the Spectacle, trans. D. Nicholson-Smith, Zone Books, New York, 1994 (Buchet-Chastel, Paris, 1967).

${ }^{80}$ J. Baudrillard, 'The Ecstasy of Communication,' trans J. Johnston, in Foster, 1983, pp. 126-134; J.

Baudrillard, Le Système des objets, Paris: Editions Gallimard, 1968; J. Baudrillard, The Ecstasy of

Communication, MIT Press, Cambridge, MA, 1988.

${ }^{81}$ J. Thackara, 'Beyond the Object in Design,' in Design after Modernism: Beyond the Object, Thames and Hudson, London, 1988, pp. 11-34. In the same volume, J. Baudrillard, 'The System of Objects,' (1968) trans. P. Sparke, pp. 171-183

${ }^{82}$ See, for example, M. Foucault, The Order of Things, Pantheon, New York, 1970.

${ }^{83}$ G. Eley, 'Nations, Publics, and Political Cultures: Placing Habermas in the Nineteenth Century', in C. Calhoun, ed., Habermas and the Public Sphere, MIT Press, London, 1993, pp. 289-296, anthologised in P. Joyce, Class, Oxford University Press, Oxford, 1995, p. 186.

${ }^{84}$ J. Habermas, 'The Public Sphere', New German Critique, no. 3 (1974), pp. 49-55. This argument was first articulated in German in Strukturwandel der Offentlichkeit, Neuwied, 1962.

${ }^{85}$ Bourdieu, 1984, p. 359.

${ }^{86}$ Ibid., p. 13.

${ }^{87}$ R. L. Blaszczyk, Imagining Consumers: Design and Innovation from Wedgwood to Corning, The Johns Hopkins University Press, Baltimore and London, 2000.

${ }^{88}$ S. Nixon and P. Du Gay, 'Who Needs Cultural Intermediaries?' Cultural Studies, vol. 16, no. 4 (2002), pp. 495-500.

${ }^{89}$ Nixon and Du Gay, 2002, p. 498.

${ }^{90} \mathrm{~K}$. Negus, 'The Work of Cultural Intermediaries and the Enduring Distance between Production and Consumption,' Cultural Studies, vol. 16, no. 4 (2002), pp. 501-515.

${ }^{91}$ L. McFall, 'What about the Old Cultural Intermediaries? An Historical Review of Advertising Producers,' Cultural Studies, vol. 16, no. 4 (2002), pp. 532-552.See, for example, Williamson, 1978.

92 J. Aynsley and K. Forde, eds., Design and the Modern Magazine, Manchester University Press, Manchester, 2007; 'Introduction', pp. 1-16.

${ }^{93}$ J. Aynsley and F. Berry, Publishing the Modern Home: Magazines and the Domestic Interior 1870-1965, a special issue of The Journal of Design History, vol. 18, no. 1 (2005). See also J. Aynsley and C. Grant, Imagined Interiors: Representing the Domestic Interior Since the Renaissance, V\&A Publications, London, 2006.

${ }^{94}$ Aynsley and Forde, eds., 2007; J. Aynsley, 'Gebrauchsgraphik as an Early Graphic Design Journal, 1924-1938', Journal of Design History, vol. 5, no. 1, (1992) pp. 53-72; J. Aynsley, 'Graphic Change: Design Change: Magazines for the Domestic Interior, 1890-1930,' Journal of Design History, vol. 18, no. 1 (2005), pp. 43-59; E. M. Thomson, 'Early Graphic Design Periodicals in America,' Journal of Design History, vol. 7, no. 2 (1994), pp. 113-126; J. Seddon, 'The Architect and the "Arch-Pedant": Sadie Speight, Nikolaus Pevsner and "Design Review," Journal of Design History vol. 20, no. 1, pp. 29-41; S. Sellers, "'How Long Has This Been Going On?" Harpers Bazaar, Funny Face and the Construction of the Modernist Woman', Visible Language, vol. 29, no. 1 (Winter 1995), pp. 12-35; B. Usherwood, 'Transnational Publishing: the Case of Elle Decoration, in M. Nava, A. Blake, I. MacRury and B. Richards, eds., Buy This Book: Studies in Advertising and Consumption, Routledge, London, 1997, pp. 178-190; D. Hebdige, 'The Bottom Line on Planet One: Squaring Up to The Face,' in Hebdige, 1988, pp. 155- 176; P. Jobling, 'The Face' in Fashion Spreads: Word and Image in Fashion Photography since 1980, Berg, Oxford, 1999, pp. 35-48; J. Scanlon, Inarticulate Longings: the Ladies' Home Journal, Gender and the Promises of Consumer Culture, Routledge, London, 1995.

${ }^{95}$ O. Máčel, 'Avant-Garde Design and the Law: Litigation over the Cantilever Chair,' Journal of Design History, vol. 3, no. 2/3 (1990), pp. 125-143; C. J. Ishino, 'Seeing is Believing: Reflections on Video Oral Histories with Chinese Graphic Designers', Journal of Design History vol. 19, no. 4, pp. 319-331. 
${ }^{96}$ M. Jones, 'Design and the Domestic Persuader: Television and the British Broadcasting Corporations Promotion of Post-war "Good Design"', Journal of Design History, vol. 16, no. 1 (2003), pp. 307-318; J. Tobias, 'Truth to Materials: Modernism and US Television News Design since 1940,' Journal of Design History, vol. 18, no. 2 (2005), pp. 179-190.

${ }^{97}$ P. Sparke, B. Martin and T. Keeble, eds., The Modern Period Room: the Construction of the Exhibited Interior 1870-1950, Routledge, London, 2006; D. S. Ryan, The Ideal Home Through the Twentieth Century, Hazar Publishing, London, 1997 and "'All the World and Her Husband": The Daily Mail Ideal Home Exhibition, 1908-1939' in M. Andrews and M. M. Talbot, eds., All the World and Her Husband: Women in Twentieth-Century Consumer Culture, Cassell, London and New York, 2000, pp. 10-22; M. Obniski, 'Exhibiting Modernity through the Lens of Tradition in Gilbert Rohde's Design for Living Interior,' Journal of Design History, vol. 20, no. (2007), pp. 227-242.

${ }^{98}$ E. Ferry, "'Decorators May be Compared to Doctors" An Analysis of Rhoda and Agnes Garrett's Suggestions for House Decoration in Painting, Woodwork and Furniture (1876)', Journal of Design History, vol. 16, no. 1 (2003), pp. 15-33; P. Sparke, "The "Ideal " and the " Real " Interior in Elsie de Wolfe's The House in Good Taste of 1913,' Journal of Design History, vol. 16, no. 1 (2003), pp. 63-76; Lees-Maffei, 2003 and G. Lees-Maffei, 'From service to self-service: advice literature as design discourse, 1920-1970', Journal of Design History, vol. 14, no. 3 (2001) pp. 187 - 206.

${ }^{99}$ Julier and Narotsky, 1998, n.p. refer to Fine and Leopold, 1993; D. Chaney, Lifestyles, Routledge, London, 1996; S. Lash and J. Urry, Economies of Signs and Spaces, Sage, London, 1994.

${ }^{100}$ Kopytoff, 1986, p. 90.

${ }^{101}$ Ibid., p. 83.

${ }^{102}$ Ibid., pp. 66-67.

${ }^{103}$ Ibid., 1986, p. 88.

${ }^{104}$ Walker, pp. 100-103, pp. 110-118, pp. 45-67.

${ }^{105}$ Meikle, 1998, p. 193. Also, J. L. Meikle, 'Preface to the Second Edition,' Twentieth Century Limited: Industrial Design in America, 1925-1939, Temple University Press, Philadelphia, PA, second edition 2001 (1979).

${ }^{106}$ Julier and Narotsky, 1998, n.p.

${ }^{107}$ Ibid., n.p.

${ }^{108}$ Ibid., n.p.

${ }^{109}$ N. Whiteley, 'Design History or Design Studies?' Design Issues, vol. 11, no. 1, (1995), pp. 38-42, p. 41.

${ }^{110}$ Fry, 1988, pp. 55.

${ }^{111}$ L. Spigel, Make Room for TV: Television and the Family Ideal in Postwar America, University of Chicago Press, Chicago, 1992; L. Spigel, Welcome to the Dreamhouse: Popular Media and Postwar Suburbs, Duke University Press, Durham, NC, 2001.

${ }^{112}$ D. Raizman, History of Modern Design, Laurence King Publishing Ltd., London, 2003. 